\title{
The Changing Profile of University Library Directors, 1966-1981
}

\author{
Ronald Dale Karr
}

Characteristics of directors of ARL academic libraries in 1966 and 1981 were compared to gauge the degree of change that occurred at the highest levels of university libraries. In both years directors were predominantly middle-aged male graduates of liberal arts programs. Significant differences were observed, however, in the directors' regions of origin, library education, additional graduate degrees, and career patterns. This evidence suggests that competition for directorships has intensified because of an enlarged pool of potential candidates.

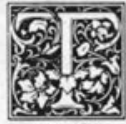

he late 1960 s and 1970 s are remembered as years of innovation and upheaval, a time when traditional life-styles and institutional procedures were challenged by new attitudes and technological advances. Universities were on the cutting edge of this transformation; even academic libraries were not immune. But how substantive were these changes? Did they reach the highest levels in major university libraries? Were library directors in the early 1980 s a different breed than their predecessors in the mid-1960s?

To explore these questions I compiled data on the origins, education, and career patterns of the men and women who in 1981 directed the ninety U.S. academic libraries affiliated with the Association of Research Libraries. For comparison I gathered similar information on the directors of these same ninety libraries in 1966. Who's Who in Library and Information Services and its predecessors provided the biographical details. ${ }^{1}$ Libraries with vacancies, acting directors, or nonlibrarians serving as directors were excluded.

\section{ORIGINS}

Gender is one of the more notable differ- ences between the directors of 1966 and 1981. In 1966 only one library (SUNY-Albany) was headed by a woman; by 1981 twelve had female directors (14 percent of the filled positions). But since two thirds of all academic librarians are female, women continued to be underrepresented at this level. ${ }^{2}$

Directors came from all parts of the country, although some regions produced more than others. Table 1 shows the birthplaces of the 1966 and 1981 directors by federal census regions, and for comparison indicates the distribution of the U.S. population in 1910 and 1930, the years closest to the mean birth date of each group. In 1966 a disproportionate number of directors came from the west north central states (Minnesota, Iowa, Missouri, North Dakota, South Dakota, Nebraska, and Kansas) and the Pacific states, while the New England and east north central (the Great Lakes states) regions were underrepresented. Fifteen years later the pattern was reversed. In both years only a handful of directors were foreign-born.

\section{EDUCATION}

Future directors attended a variety of undergraduate institutions, ranging from

Ronald Dale Karr is public services librarian at the Transportation Library, Northwestern University Library, Evanston, Illinois 60201. 
TABLE 1

BIRTHPLACES OF DIRECTORS BY REGION

\begin{tabular}{|c|c|c|c|c|c|c|}
\hline Region* & No. & $\%$ & $\begin{array}{l}\text { Distribution } \\
\text { of U.S. } \\
\text { Pop.. } 1910 \\
\%_{\%}\end{array}$ & No. & 1981 & $\begin{array}{c}\text { Distribution } \\
\text { of U.S. } \\
\text { Pop. } 1930 \\
\%\end{array}$ \\
\hline New England & 4 & 5 & 7 & 9 & 11 & 7 \\
\hline Middle Atlantic & 13 & 16 & 21 & 18 & 22 & 21 \\
\hline East North Central & 13 & 16 & 20 & 17 & 21 & 21 \\
\hline West North Central & 16 & 20 & 13 & 8 & 10 & 11 \\
\hline South Atlantic & 9 & 11 & 13 & 7 & 9 & 13 \\
\hline East South Central & 5 & 6 & 9 & 5 & 6 & 8 \\
\hline West South Central & 7 & 9 & 10 & 4 & 5 & 10 \\
\hline Mountain & 2 & 2 & 3 & 3 & 4 & 3 \\
\hline Pacific & 8 & 10 & 5 & 3 & 4 & 7 \\
\hline Foreign-born & 5 & 6 & - & 7 & 9 & - \\
\hline Total & 82 & 101 & 101 & 81 & 101 & 101 \\
\hline
\end{tabular}

Unknown: 1966,$1 ; 1981,4$.

"New England: Me., N.H., Vt., Mass., Conn., R.I.; middle Atlantic: N.Y., N.J., Pa.; east north central: Ohio, Ind., Ill., Mich., Wis.; west north central: Minn., Iowa, Mo., N.D., S.D., Nebr., Kans.; south Atlantic: Del., Md., D.C., Va., W.Va., N.C., S.C., Ga., Fla.; east south central: Ky., Tenn., Ala., Miss.; west south central: Ark., La., Okla., Tex.; mountain: Mont., Id., Wy., Colo., N.M., Ariz., Utah, Nev.; Pacific: Wash., Oreg., Calif., Alaska, Hawaii.

prominent universities to obscure colleges. The 1966 directors were more likely to have graduated from prestigious institutions than were their successors in 1981. Nine directors in the 1966 group were alumni of Ivy League schools (Columbia, Harvard, Dartmouth, and Yale), and three others attended universities of comparable renown (Stanford and the University of Chicago). In contrast, only three of the 1981 directors received undergraduate degrees from Ivy League or elite colleges (Harvard, Chicago, and Swarthmore).

English and history were the most popular undergraduate majors among both groups of future directors, with nearly half taking their degrees in these two areas. In all, 80 percent of the 1966 directors and 75 percent of the 1981 contingent had majored in the liberal arts (see table 2).

The two groups showed significant differences in the library education they received. In 1966 twelve directors - 15 percent of the total-lacked library degrees; by 1981 every ARL director was a graduate of a certified graduate library program. Moreover, the 1966 directors who had attended library school were largely products of a few select universities: 68 percent had obtained their initial professional degrees from just three schools-Columbia, Michigan, and Illinois. None of the other fifteen library schools represented could
TABLE 2

\section{UNDERGRADUATE MAJOR SUBJECT} AREAS OF DIRECTORS

\begin{tabular}{lrrrr}
\hline Field & \multicolumn{2}{c}{1966} & \multicolumn{2}{c}{1981} \\
\hline Liberal Arts & No. & $\%$ & \multicolumn{1}{c}{ No. } & \multicolumn{1}{c}{$\%$} \\
$\quad$ English & 57 & 80 & 55 & 75 \\
History & 23 & 32 & 22 & 30 \\
Humanities & 13 & 18 & 12 & 16 \\
Social Science & 13 & 18 & 10 & 14 \\
Education & 8 & 11 & 11 & 15 \\
Business & 1 & 1 & 3 & 4 \\
Library Science & 1 & 1 & 1 & 1 \\
Journalism & 1 & 1 & 1 & 1 \\
Science-Engineering & 1 & 1 & 0 & 0 \\
$\quad 10$ & 14 & 13 & 18 \\
$\quad$ Total & 71 & 98 & 73 & 99 \\
\hline
\end{tabular}

Unknown: 1966, 12; 1981, 12.

claim more than two alumni among the directors (see table 3 ).

In contrast, the three library schools most frequently attended by the 1981 directors (Columbia, Michigan, and Simmons) accounted for only 37 percent of the group. Not even the top five institutions could claim more than half of the directors. Simmons College, which was not attended by any of the 1966 directors, had edged out the University of Illinois with six alumni. In all, the 1966 directors were graduates of only eighteen different library schools; their successors in 1981 had attended no less than thirty.

Both before and after stints in library 
TABLE 3

LIBRARY SCHOOLS ATTENDED BY DIRECTORS (FIRST PROFESSIONAL DEGREES)

\begin{tabular}{ll}
\hline \hline 1966 & 1981 \\
\hline 1. Columbia (21) & 1. Columbia (14) \\
2. Michigan (14) & 2. Michigan (10) \\
3. Illinois (12) & 3. Simmons (6) \\
15 other schools (22) & 4. Chicago (5) \\
No degree (12) & Illinois (5) \\
& 25 other schools (41) \\
\hline
\end{tabular}

Unknown: 1966, 2; 1981, 4.

school, most directors obtained additional academic degrees. Given the great expansion in graduate education that has characterized the past few decades, one might have expected the 1981 directors to be the better educated; but this was not the case (see table 4). To be sure, all directors in the 1981 group held at least a master's degree, compared to 93 percent in the 1966 group. But, surprisingly, the proportion of directors with doctorates fell from nearly half in 1966 to one third in 1981. A second master's degree in a subject area had become an acceptable substitute for the doctorate.

\section{CAREER PATTERNS}

Future directors of major university libraries usually launched their careers in academic libraries, a tendency that is becoming increasingly pronounced. In 1966, 71 percent of the directors had started in academic libraries; by 1981 that figure had reached 79 percent (see table 5 ). (Similarly, directors of large public libraries usually begin in public libraries). ${ }^{3}$ Future directors most frequently found their initial professional positions in the public services area (see table 6). One third of the 1966 directors, however, had gone directly into library administration; only 12 percent of their successors in 1981 held their first jobs in this area. No less than twelve (16 percent) of the 1966 group had started their library careers as directors (usually of small academic libraries), compared to only four (5 percent) in 1981.

The 1966 directors rose faster to the top than did their successors in 1981. Members of the 1966 group obtained their initial directorship at a mean age of 36.7 years, compared to 39.2 years for the 1981 contingent. The 1966 directors averaged 42.1 years when they assumed their current post; their successors, 44.5 years. Along the way the 1966 directors were employed at an average of 3.7 libraries; the 1981 group, 4.0. Ten directors (12 percent) in 1966 had spent their entire library careers at a single institution, compared to six (8 percent) in 1981.

In the course of their careers most directors moved away from their birthplaces. Only 17 percent of the 1966 group had been born in the same states as their li-

TABLE 4

HIGHEST ACADEMIC DEGREE OBTAINED BY DIRECTORS

\begin{tabular}{|c|c|c|c|c|}
\hline Degree & No. & $\%$ & No. & $\%$ \\
\hline Bachelor's & 6 & 7 & 0 & 0 \\
\hline MLS & 20 & 25 & 31 & 38 \\
\hline MLS/BLS + 2d Master's & 11 & 14 & 22 & 27 \\
\hline MLS + Law & 1 & 1 & 1 & 1 \\
\hline MLS/BLS + Ph.D (LS) & 22 & 27 & 18 & 22 \\
\hline MLS/BLS + Ph.D (Subj.) & 10 & 12 & 9 & 11 \\
\hline Master's, no MLS/BLS & 7 & 8 & 0 & 0 \\
\hline Ph.D, no MLS/BLS & 4 & 5 & 0 & 0 \\
\hline Total & 81 & 99 & 81 & 99 \\
\hline
\end{tabular}

Unknown: 1966, 2; 1981, 4. 
TABLE 5

INITIAL PROFESSIONAL POSITION BY TYPE OF LIBRARY

\begin{tabular}{|c|c|c|c|c|}
\hline \multirow[b]{2}{*}{ Type } & \multicolumn{2}{|c|}{1966} & \multicolumn{2}{|c|}{1981} \\
\hline & No. & $\%$ & No. & $\%$ \\
\hline Academic & 58 & 71 & 62 & 79 \\
\hline Public & 15 & 18 & 9 & 12 \\
\hline Special & 4 & 5 & 7 & 9 \\
\hline School & 5 & 6 & 0 & 0 \\
\hline Total & 82 & 100 & 78 & 100 \\
\hline
\end{tabular}

Unknown: 1966,$1 ; 1981,7$

TABLE 6

INITIAL PROFESSIONAL POSITION BY FUNCTION

\begin{tabular}{lrrrr}
\hline Function & No. & \multicolumn{2}{c}{$\%$} & \multicolumn{1}{c}{ No. ${ }^{1986} \%$} \\
\hline Public & & & & \\
$\quad$ Services & 32 & 43 & 39 & 53 \\
Technical & & & & \\
$\quad$ Services & 13 & 17 & 21 & 28 \\
Administration & 25 & 33 & 9 & 12 \\
Other & 5 & 7 & 5 & 7 \\
$\quad$ Total & 75 & 100 & 74 & 100 \\
\hline
\end{tabular}

Unknown: 1966, 8; 1981, 11

- Public services includes reference, circulation, serials/periodicals, subject specialists, government documents, law, and maps; technical services includes cataloging, acquisitions, gifts and exchanges, and orders; administration includes directors, administrative aides, assistant or associate directors, and high school librarians; other includes computer personnel, bibliographers, and rare book librarians.

braries were located, 30 percent in the same census regions. The 1981 directors were even more mobile: 14 percent had originated in the same states and 28 percent in the same regions.

Although the 1981 directors had taken longer to reach their present positions than their predecessors, they were younger: their mean age was 51.2 years, compared to 53.6 among the 1966 contingent. This resulted from the presence of newer directors in the 1981 group. The 1981 directors had served in their current positions an average of 6.7 years, as opposed to 11.4 years among the 1966 group.

\section{CONCLUSIONS}

The limited evidence considered here suggests that the profile of the academic library director has indeed changed. The typical director of the mid-1960s-almost exclusively male-entered the profession in the 1930 s or 1940 s, when trained librari- ans were relatively scarce. During the Great Depression, college graduates found jobs hard to obtain in business and teaching, even with advanced degrees; moreover, as a "female" profession, librarianship offered advantages for the few men willing to enter it. Most future directors attended one of three library schools, which indicates that an informal "old-boy" network existed to aid their climb to the top. Fully one third of the directors-to-be began their careers in administrative posts. Universities were seemingly so anxious to staff their libraries with college-educated males that many directors found it unnecessary to obtain a library degree at all. Nine of the 1966 directors had received bachelor's degrees from the institutions whose libraries they now directed.

The directors of 1981 resembled their predecessors-most continued to be middle-aged male liberal arts graduatesbut differences are striking. Women were no longer unrepresented. Fewer directors had attended elite undergraduate colleges, and the three library schools that had provided the bulk of the 1966 directors could claim a much smaller proportion of their successors. The 1981 directors found it harder to reach the top; few began in administrative posts and the climb to that first directorship and their present positions took longer. Even so, the 1981 directors were younger and less entrenched in their jobs and their institutions. Only two held undergraduate degrees from the universities at which they now were employed.

Over the past few decades the environment of large academic libraries seems to have become more competitive, structured, and bureaucratic. The pool of potential directors has grown much larger, while the number of top positions remains fixed. Women and graduates of less distinguished library schools can no longer be excluded from the competition. The networks that once eased the paths to the top for a fortunate few have weakened. In short-dare we say?-the genteel, scholarly, even dilettantish directors of the past are yielding to career-minded managers, administrators, and technicians. 


\section{REFERENCES}

1. Joel M. Lee, ed., Who's Who in Library and Information Services (Chicago: ALA, 1982); Lee Ash and B. A. Uhlendorf, eds., A Biographical Directory of Librarians in the United States and Canada (Chicago: ALA, 1970); Lee Ash, ed., Who's Who in Library Service (Hamden, Conn.: Shoe String, 1966); Dorothy Ethlyn Cole, ed., Who's Who in Library Service (New York: Grolier Society, 1955); C. C. Williamson and Alice L. Jewett, eds., Who's Who in Library Service (New York: Wilson, 1943); idem, Who's Who in Library Service (New York: Wilson, 1933). The names of the librarians were taken from the American Library Directory.

2. Michael D. Cooper, "What the Numbers Say: A Statistical Portrait of Librarians," American Libraries 7:328 (June 1976).

3. Ronald Dale Karr, "Becoming a Library Director," Library Journal 108:344 (Feb. 15, 1983). 